\title{
STABILITY INDICATING SPECTROPHOTOMETRIC AND DENSITOMETRIC METHODS FOR THE DETERMINATION OF ENROFLOXACIN AND FLUMEQUINE
}

\author{
Ola M. Abd Allah
}

Department of Analytical Chemistry, Faculty of Pharmacy (Girls), Al-Azhar University, Cairo, Egypt, E-mail: olamody@yahoo.com

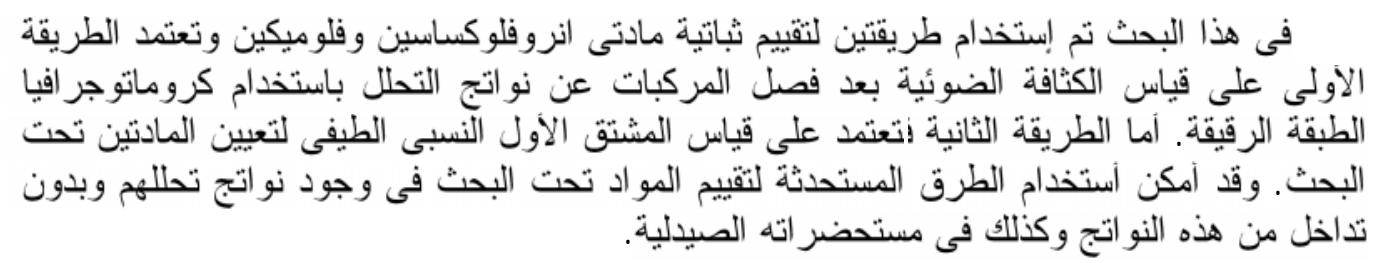

Two methods were developed for the determination of intact enrofloxacin (ER) and flumequine $(F Q)$ in presence of their degradation products. In the first method, $E R$ and $F Q$ were determined using first derivative ratio spectrophotometric technique $\left({ }^{1} \mathrm{DD}\right)$ at $290 \mathrm{~nm}$ and $260 \mathrm{~nm}$ in the ranges of 1-12 $\mu \mathrm{g} \mathrm{ml}^{-1}$ and 2-14 $\mu \mathrm{g} \mathrm{ml}^{-1}$, respectively. The second method depends on the quantitative densitometric evaluation of thin-layer chromatograms of both drugs. Good linearities were obtained in the range of 1.5-4 $\mu \mathrm{g} \mathrm{ml} \mathrm{l}^{-1}$ and 4-14 $\mu \mathrm{g} \mathrm{ml}^{-1}$ for ER and $F Q$ respectively.

The proposed procedures retained their accuracy in the presence of up to $70 \%$ degradation products for the two drugs. The results obtained by applying the proposed methods were statistically analyzed and compared with those obtained by reported methods.

\section{INTRODUCTION}

Enrofloxacin and Flumequine are synthetic antimicrobial agents of the 6fluoroquinolone family, specially designed for use in veterinary medicine. ${ }^{1}$<smiles>CCN1CCN(c2cc3c(cc2F)c(=O)c(C(=O)O)cn3C2CC2)CC1</smiles>

Enrofloxacin (ER)<smiles>CC1CCc2cc(F)cc3c(=O)c(C(=O)O)cn1c23</smiles>

Flumequine (FQ)
Several methods have been reported for the determination of ER including, HPLC, ${ }^{2-5}$ TLC $^{6}{ }^{6}$ colorimetry ${ }^{7,8}$ and voltammetry. ${ }^{9}$ Methods of analysis of FQ include HPLC, ${ }^{10-12}$ TLC, ${ }^{13}$ HPTLC, ${ }^{14}$ electrophoresis, ${ }^{15}$ colorimetry ${ }^{16}$ and polarography. ${ }^{17}$

Decarboxylation of ER and FQ decreases the pharmacological activity of both drugs since the carboxylic group is of particular importance in quinolones antibacterials. ${ }^{18}$

The purpose of this study was to determine the two drugs in the presence of their degradation products by simple, rapid and selective stability - indicating assays for quality control and routine analysis.

\section{EXPERIMENTAL}

\section{Samples}

- Reference standard enrofloxacin, Batch No. 20020326 and flumequine, Batch No. 20020735 (China Jiangsu, International 
Economic Technical Cooperation Corporation, China) were provided by ADWIA, $10^{\text {th }}$ of Ramadan City, Egypt. Their purity was checked by HPLC methods adopted by ADWIA research and development laboratories and found to be $99.30 \%$ and $99.62 \%$, respectively.

- Enrotryl 10\% injection, product of ADWIA Batch No. 030753: label claim for each ml was $100 \mathrm{mg}$ enrofloxacin.

- Flumequine $10 \%$ powder, product of ADWIA Batch No. 031068.

- Stock degraded solutions: ${ }^{19}$ prepared by refluxing $0.1 \mathrm{~g}$ of pure ER or FQ with $75 \mathrm{ml}$ $2 \mathrm{M} \mathrm{HCl}$ or $75 \mathrm{ml} 4 \mathrm{M} \mathrm{HCl}$ solution, respectively, for 36 hours then cooling and neutralizing using $5 \mathrm{M} \mathrm{NaOH}$ solution and evaporating to dryness under vacuum. Residue was extracted with ethanol for ER or methanol for $\mathrm{FQ}$, then filtered into a 100 $\mathrm{ml}$ volumetric flasks, and adjusted to volume with the indicated solvents. 6\% undegraded ER or $7 \%$ undegraded FQ was found to be present as analyzed by iron (III) chelation procedures. ${ }^{7,16}$

\section{Reagents}

- Ethanol and methanol (Fisher, England)

- Hydrochloric acid (Prolabo, France)

- Sodium hydroxide (Prolabo, France)

- Deuterated chloroform (Prolabo, France)

- Chloroform (Prolabo, France)

- Plates for thin-layer chromatography (20x20 $\mathrm{cm}$ ), precoated with silica gel GF 254, 0.20 $\mathrm{mm}$ thickness (Marcherey-Nagel, Germany).

\section{Apparatus}

- UV/VIS Spectrophotometer-Shimadzu 1601 PC attached to IBM computer and Hewlett Packard printer (Shimadzu, Japan).

- Densitometer - Dual wavelength Shimadzu flying spot CS-9000 with video display.

- IR spectra were recorded as $\mathrm{KBr}$ discs on a Shimadzu IR 200-91527 Spectrophotometer (Japan).

- Hamilton syringe $(10 \mu \mathrm{l})$.

- UV Lamp: Vilbert Lourmat, France.

\section{Procedures \\ Preparation of degradate solutions for spectrophotometric and densitometric procedures}

A volume of $10 \mathrm{ml}$ of stock degraded solutions was diluted to $100 \mathrm{ml}$ with ethanol or methanol for $\mathrm{ER}$ or $\mathrm{FQ}$, respectively. A solution containing $0.094 \mathrm{mg} \mathrm{ml}^{-1}$ degraded ER plus $0.006 \mathrm{mg} \mathrm{ml}^{-1}$ intact ER or $0.093 \mathrm{mg} \mathrm{ml}^{-1}$ degraded FQ plus $0.007 \mathrm{mg} \mathrm{ml}^{-1}$ intact FQ, was obtained.

\section{Linearity}

\section{Spectrophotometric procedure}

Different volumes of standard drug solutions (100 $\left.\mathrm{g} \mathrm{ml}^{-1}\right)$ containing 1-12 $\mathrm{g}$ ER or 2-14 g FQ, were transferred into a series of $10 \mathrm{ml}$ volumetric flasks, then diluted to volume with ethanol for ER and methanol for FQ. First derivative of the ratio spectra of both drugs were recorded against the respective solvent as blank at $\Delta \lambda=2$ and ordinate values of $(0.005$ and -0.095$)$ or $(0.005$ and -0.1$)$ for ER or FQ, respectively. Peak height at $290 \mathrm{~nm}$ (ER) or $260 \mathrm{~nm}$ (FQ) as maxima and zero-crossing lines as minima were measured. Calibration curves relating the measured heights in $(\mathrm{mm})$ and drug concentrations in $\mathrm{g} \mathrm{ml}^{-1}$ were constructed.

\section{Densitometric procedure}

Aliquots of ER or FQ standard solutions $\left(0.1 \mathrm{mg} \mathrm{ml}^{-1}\right)$ containing 1.5-4 g ER or 4-14 $\mathrm{g}$ FQ were transferred into a series of $10 \mathrm{ml}$ volumetric flasks. Ten microlitres of each solution were applied to a TLC plate $(20 \times 20$ $\mathrm{cm}$ ) using a $10 \quad 1$ syringe. Spots were spaced 2 $\mathrm{cm}$ apart from each other and $1.5 \mathrm{~cm}$ from the edge of the plate. The plate was placed in a chromatographic tank previously saturated for $1 \mathrm{~h}$ with mobile phase of chloroform-methanol $(4: 9, \mathrm{v} / \mathrm{v})$ or $(3: 9, \mathrm{v} / \mathrm{v})$ for ER or FQ. The plates were developed to $16 \mathrm{~cm}$ then removed and airdried. Spots were detected under UV- lamp and scanned at $240 \mathrm{~nm}$ for ER and at $280 \mathrm{~nm}$ for FQ (photo mode: reflection; scan mode: zigzag). The calibration curves representing the relationship between the recorded area under the peak and the corresponding concentration were plotted. 


\section{Assay of pharmaceutical formulations Determination of ER in Enrotryl injection}

A volume of $0.5 \mathrm{ml}$ of the injection (equivalent to $50 \mathrm{mg} \mathrm{ER}$ ) was transferred into $50 \mathrm{ml}$ volumetric flask, then diluted to volume with ethanol and mixed $\left(1 \mathrm{mg} \mathrm{ml}^{-1}\right)$. An aliquot of this solution was diluted to obtain a concentration of $0.1 \mathrm{mg} \mathrm{ml}^{-1}$. The obtained solution was analyzed by derivative ratio and densitometric procedures, as described under linearity.

\section{Determination of FQ in flumequine $10 \%$ powder}

Three preparations were mixed. Powder equivalent to $10 \mathrm{mg}$ FQ was accurately weighed, dissolved in methanol by shaking for $20 \mathrm{~min}$, then diluted to $100 \mathrm{ml}$. The obtained solution was filtered and the filtrate was analyzed by the spectrophotometric and densitometric procedures, as mentioned under linearity.

\section{RESULTS AND DISCUSSION}

\section{Degradation of ER and FQ}

The two fluroquinolones under study were expected to undergo decarboxylation reaction when heated with $2 \mathrm{M} \mathrm{HCl}$ at $100^{\circ}$ for 15 hours, as reported for norfloxacin. ${ }^{20}$ Only $50 \%$ degradation was obtained under these conditions. Maximum degradation ( $94 \%$ for ER and $93 \%$ for $\mathrm{FQ}$ ) was attained by boiling the acid solution for $36 \mathrm{hrs}$ and using $2 \mathrm{M} \mathrm{HCl}$ for $\mathrm{ER}$ and $4 \mathrm{M} \mathrm{HCl}$ for $\mathrm{FQ}$.

\section{Spectrophotometric procedure}

Zero-order absorption spectra of intact drugs and their degradates were found to be extensively overlapped. (Figs. 1 and 2). Such overlapping was omitted by adopting the derivative of the ratio spectra method. The main advantage of this method may be the chance of doing measurements in correspondence of peaks, hence a potential greater sensitivity and accuracy. While the main disadvantages of the zero crossing method in derivative spectrophotometry for resolving a mixture of components with overlapped spectra are the risk of small drifts of the working wavelengths. This may be particularly dangerous when the slope of the spectrum is very high with consequent loss of accuracy and precision. In this procedure, the UV absorption spectra of intact ER and FQ were divided by a definite spectrum of their degradates, the first derivative was then calculated and measured at $290 \mathrm{~nm}$ for ER and at $260 \mathrm{~nm}$ for FQ, (Figs. 3 and 4). The corresponding regression parameters are shown in Table (1).

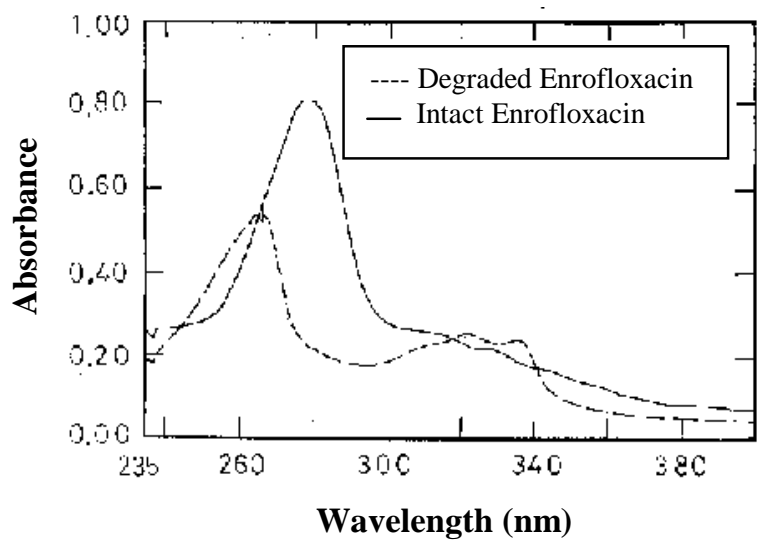

Fig. 1: Absorption spectra of: Intact ER, $6 \mathrm{~g} \mathrm{ml}^{-1}$ $(-)$, Degraded ER, $6 \mathrm{~g} \mathrm{ml}^{-1}$ (----) in ethanol.

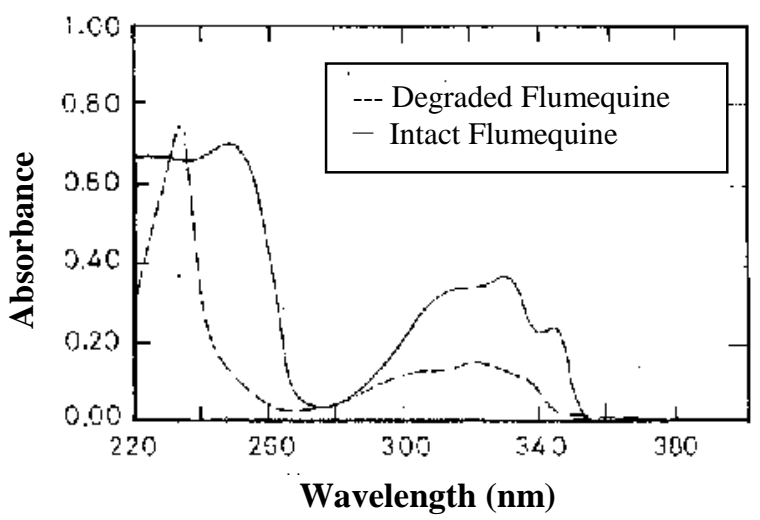

Fig. 2: Absorption spectra of: Intact FQ, $8 \mu \mathrm{g} \mathrm{ml}^{-1}$ $(-)$, Degraded FQ, $6 \mu \mathrm{g} \mathrm{ml}^{-1}$ (---) in methanol. 


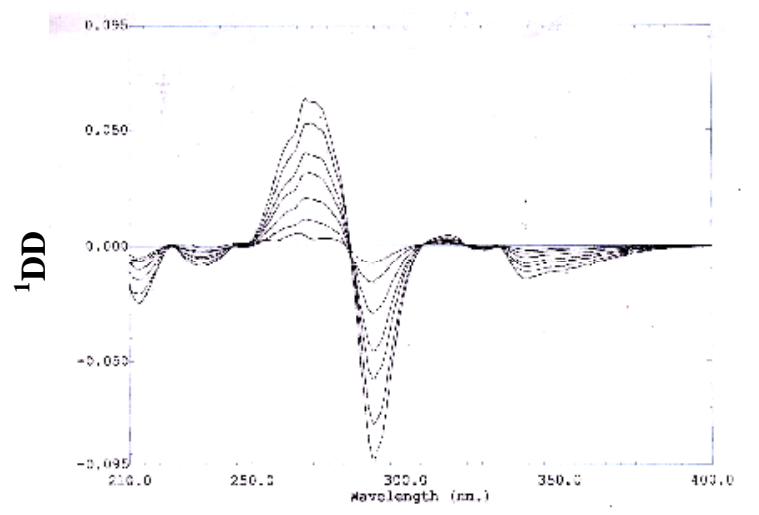

Fig. 3: First derivative ratio spectra of ER in presence of its degradate (using 1-12 g $\left.\mathrm{ml}^{-1} \mathrm{ER}\right)$ in methanol and $6 \mathrm{~g} \mathrm{ml}^{-1}$ of its degradate as a divisor.

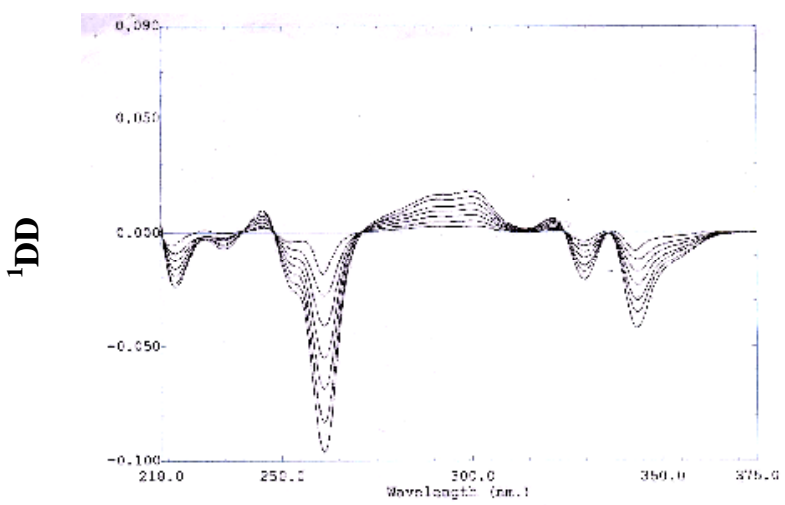

Fig. 4: First derivative ratio spectra of FQ in presence of its degradate (using 2-14 $\mathrm{g} \mathrm{ml}^{-}$ FQ) in methanol and $6 \mathrm{gml}^{-1}$ of its degradate as a divisor.

Table 1: Selected spectral data for the determination of ER and FQ by the proposed procedures.

\begin{tabular}{|l|c|c|c|c|}
\hline \multirow{2}{*}{ Parameters } & \multicolumn{2}{|c|}{ Enrofloxacin } & \multicolumn{2}{c|}{ Flumequine } \\
\cline { 2 - 5 } & ${ }^{1} \mathrm{DD}$ & Densitometric & ${ }^{1} \mathrm{DD}$ & Densitometric \\
\hline $\begin{array}{l}\text { Linearity range } \\
\left(\mu \mathrm{g} \mathrm{ml}^{-1}\right)\end{array}$ & $1-12$ & $1.5-4$ & $2-14$ & $4-14$ \\
\hline $\mathrm{LOD}\left(\mu \mathrm{g} \mathrm{ml}^{-1}\right)$ & 0.6 & 0.5 & 0.6 & 2 \\
\hline LOQ $\left(\mu \mathrm{g} \mathrm{ml}^{-1}\right)$ & 0.8 & 1 & 1 & 3 \\
\hline $\begin{array}{l}\text { Regression } \\
\text { parameters } \\
\text { Slope } \pm \mathrm{SD}\left(\mathrm{s}_{\mathrm{b}}\right)\end{array}$ & $0.967 \pm 0.027$ & $2.449 \pm 0.021$ & $0.805 \pm 0.005$ & $1.33 \pm 0.021$ \\
$\begin{array}{l}\text { Intercept } \pm \mathrm{SD}\left(\mathrm{s}_{\mathrm{a}}\right) \\
\text { SD of residual }\left(\mathrm{s}_{\mathrm{xy}}\right)\end{array}$ & $-0.074 \pm 0.195$ & $-0.008 \pm 0.062$ & $0.057 \pm 0.048$ & $0.307 \pm 0.20$ \\
\hline $\begin{array}{l}\text { Correlation } \\
\text { coefficient }\end{array}$ & 0.074 & 0.002 & 0.003 & 0.032 \\
\hline $\begin{array}{l}\text { Accuracy* } \\
\text { Intraday R\% } \\
\text { Interday R\% }\end{array}$ & $\begin{array}{c}99.5-101 \\
99.8-102.0\end{array}$ & $\begin{array}{c}100.9-102.2 \\
98.0-101.5\end{array}$ & $\begin{array}{c}101.6-102.3 \\
100.8-102.0\end{array}$ & $\begin{array}{c}99.9-101.6 \\
98.5-102.8\end{array}$ \\
\hline $\begin{array}{l}\text { Precision* } \\
\text { Intraday RSD } \\
\text { Interday RSD }\end{array}$ & $\begin{array}{c}1.21-2.55 \\
0.23-1.05\end{array}$ & $\begin{array}{c}0.25-0.55 \\
0.69-1.72\end{array}$ & $\begin{array}{c}0.81-1.54 \\
0.19-0.31\end{array}$ & $\begin{array}{l}0.16-0.66 \\
0.34-2.30\end{array}$ \\
\hline
\end{tabular}

$*_{\mathrm{n}}=4$ 


\section{Densitometric procedure}

The second procedure for eliminating interference due to degradation products is concerned with the application of densitometric technique. The method depends on the difference of the $R_{f}$ values of the drug and its degradation product. Complete separation of ER $\left(R_{\mathrm{f}}=0.25\right)$ and its degradate $\left(\mathrm{R}_{\mathrm{f}}=0.65\right)$ using a mobile phase of chloroform - methanol (4: 9, v/v) while $R_{f}$ values of intact and degraded FQ were 0.17 and 0.82 , respectively, using a mobile phase of chloroform - methanol $(3: 9, v / v)$. The chromatograms were scanned quantitatively at 280 and $250 \mathrm{~nm}$ for ER and $\mathrm{FQ}$, respectively. The corresponding regression equations were computed and their parameters are illustrated in Table (1). Interday and interday precision (RSD\%) were ranged between $0.23-2.55 \%$, which prove that the proposed procedures are accurate and precise, Table (1).

The specificity of the procedures was tested by analyzing laboratory-prepared mixtures of the drugs and their degradates in different ratios, no interferences were found in the presence of degradation products at the levels of $\sim 70 \%$. The results are shown in Tables (2 and 3).

The proposed procedures were also applied for the determination of both drugs in their pharmaceutical formulations, results illustrated in Tables (4 and 5) showed no interference from excipients or additives when applying the technique of standard addition.

Table (6) shows that the calculated $\mathrm{t}$ and $\mathrm{F}$ values are less than the corresponding theoretical values, indicating that there is no significant difference between the proposed methods and reported methods with respect to precision and accuracy at $95 \%$ confidence limits.

\section{Confirmation of the degradation products}

The degradates were separated on preparative plates using the respective eluting system and extracted with chloroform, the extracts were evaporated to dryness and then confirmed in the residues by IR and ${ }^{1} \mathrm{HNMR}$. IR spectra of degraded ER and FQ show complete disappearance of the band at 1700 $\mathrm{cm}^{-1}$ which characterizes the carbonyl moiety of the carboxylic group in the intact drugs which confirm decarboxylation. The ${ }^{1} \mathrm{HNMR}$ spectra of pure drugs in $\mathrm{CDCL}_{3}$ are characterized by a sharp singlet at $\sim 8.5 \mathrm{ppm}$ due to the $\mathrm{CH}$ proton in position 2. While the ${ }^{1}$ HNMR of the degradation products spectra revealed two new doublets at $\sim 7.5$ and $6.0 \mathrm{ppm}$ which correspond to the $\mathrm{CH}$ proton at position 2 and the new $\mathrm{CH}$ proton in position 3 produced as a result of decarboxylation.

Table 2: Determination of enrofloxacin and flumequine in mixtures with their decarboxylated degradates by the proposed derivative ratio procedure.

\begin{tabular}{|c|c|c|c|c|c|c|c|}
\hline \multicolumn{4}{|c|}{ Enrofloxacin } & \multicolumn{4}{|c|}{ Flumequine } \\
\hline $\begin{array}{l}\text { Intact* }^{*} \\
\mathrm{~g} \mathrm{ml}^{-1}\end{array}$ & $\begin{array}{c}\text { Degradate } \\
\mu \mathrm{g} \mathrm{ml}^{-1}\end{array}$ & $\begin{array}{c}\text { Degradate }^{* *} \\
\%\end{array}$ & $\begin{array}{c}\text { Recovery \% } \\
\text { of intact }\end{array}$ & $\begin{array}{l}\text { Intact* }^{*} \\
\mu \mathrm{g} \mathrm{ml}^{-1}\end{array}$ & $\begin{array}{c}\text { Degradate } \\
\mu \mathrm{g} \mathrm{ml}^{-1}\end{array}$ & $\begin{array}{c}\text { Degradate }^{* *} \\
\%\end{array}$ & $\begin{array}{c}\text { Recovery \% } \\
\text { of intact }\end{array}$ \\
\hline 12.24 & 3.76 & 23.5 & 98.4 & 14.14 & 1.86 & 11.5 & 102.9 \\
\hline 10.36 & 5.64 & 35.2 & 100.4 & 12.28 & 3.72 & 23.2 & 99.2 \\
\hline 8.48 & 7.52 & 47.0 & 102.5 & 10.42 & 5.58 & 34.8 & 100.2 \\
\hline 6.60 & 9.4 & 58.7 & 103.0 & 8.56 & 7.44 & 46.50 & 102.9 \\
\hline 4.72 & 11.28 & 70.5 & 100.0 & 6.70 & 9.30 & 58.10 & 98.0 \\
\hline $2.84^{* * * *}$ & 13.16 & 82.0 & 128 & 4.84 & 11.16 & 69.70 & 99.5 \\
\hline & & & & $2.98^{* * * *}$ & 13.02 & 81.3 & 128 \\
\hline $\begin{array}{l}\text { Mean } \pm \\
\text { RSD\% }\end{array}$ & & & $100.86 \pm 1.88$ & & & & $100.46 \pm 2.01$ \\
\hline
\end{tabular}

* Taken + undegraded part in the hydrolysed solutions; $6 \%$ for ER and $7 \%$ for FQ.

** of the total weight.

**** Rejected. 
Table 3: Determination of enrofloxacin and flumequine in mixtures with their decarboxylated degradates by the proposed densitometric procedure.

\begin{tabular}{|c|c|c|c|c|c|c|c|}
\hline \multicolumn{4}{|c|}{ Enrofloxacin } & \multicolumn{4}{|c|}{ Flumequine } \\
\hline $\begin{array}{l}\text { Intact* }^{*} \\
\mu \mathrm{g} \mathrm{ml}^{-1}\end{array}$ & $\begin{array}{c}\text { Degradate } \\
\mu \mathrm{g} \mathrm{ml}^{-1}\end{array}$ & $\begin{array}{c}\text { Degradate** } \\
\%\end{array}$ & $\begin{array}{l}\text { Recovery } \\
\% \text { of intact }\end{array}$ & $\begin{array}{l}\text { Intact* }^{*} \\
\mu \mathrm{g} \mathrm{ml}^{-1}\end{array}$ & $\begin{array}{c}\text { Degradate } \\
\mu \mathrm{g} \mathrm{ml}^{-1}\end{array}$ & $\begin{array}{c}\text { Degradate** } \\
\%\end{array}$ & $\begin{array}{c}\text { Recovery\% } \\
\text { of intact }\end{array}$ \\
\hline 4.14 & 1.86 & 31.0 & 99.03 & 12.24 & 3.76 & 23.5 & 99.8 \\
\hline 3.67 & 2.32 & 38.6 & 98.63 & 10.36 & 5.64 & 35.2 & 100.4 \\
\hline 3.21 & 2.79 & 46.5 & 99.73 & 8.48 & 7.52 & 47.0 & 101.2 \\
\hline 2.74 & 3.25 & 54.1 & 99.04 & 6.60 & 9.40 & 58.7 & 101.6 \\
\hline 2.28 & 3.72 & 62.0 & 100.32 & 4.72 & 11.28 & 70.5 & 99.2 \\
\hline 1.81 & 4.18 & 69.6 & 99.88 & $2.84^{* * *}$ & 13.16 & 82.2 & 122.0 \\
\hline $1.35^{\text {**** }}$ & 4.65 & 77.5 & 111.70 & & & & \\
\hline \multicolumn{3}{|c|}{ Mean \pm RSD \% } & $99.4 \pm 0.63$ & & & & $100.4 \pm 0.96$ \\
\hline
\end{tabular}

* Taken + undegraded part in the hydrolysed solutions; $6 \%$ for ER and 7\% for FQ.

** of the total weight.

*** Rejected.

Table 4: Recovery of ER and FQ in their pharmaceutical formulations by the proposed derivative ratio procedure.

\begin{tabular}{|c|c|c|c|c|c|c|c|c|c|}
\hline \multicolumn{5}{|c|}{ Enrofloxacin } & \multicolumn{5}{|c|}{ Flumequine } \\
\hline & \multirow[b]{2}{*}{$\begin{array}{c}\text { Mean* } \\
\pm \\
\text { RSD\% }\end{array}$} & \multicolumn{3}{|c|}{ Standard addition } & & \multirow[b]{2}{*}{$\begin{array}{c}\text { Mean* } \\
\pm \\
\text { RSD\% }\end{array}$} & \multicolumn{3}{|c|}{ Standard addition } \\
\hline & & $\begin{array}{l}\text { Taken } \\
\mu \mathrm{g} \mathrm{ml}^{-1}\end{array}$ & $\begin{array}{l}\text { Added } \\
\mu \mathrm{g} \mathrm{ml}^{-1}\end{array}$ & $\begin{array}{c}\text { Recovery } \\
\% \\
\text { of added }\end{array}$ & & & $\begin{array}{l}\text { Taken } \\
\mu \mathrm{g} \mathrm{ml}^{-1}\end{array}$ & $\begin{array}{l}\text { Added } \\
\mu \mathrm{g} \mathrm{ml}^{-1}\end{array}$ & $\begin{array}{c}\text { Recovery } \\
\% \\
\text { of added }\end{array}$ \\
\hline \multirow{4}{*}{$\begin{array}{l}\text { Enrotryl } \\
10 \% \text { inj. }\end{array}$} & $100.8 \pm$ & 2 & 2 & 102.6 & Flumequine & 100.1 & 2 & 2 & 101.70 \\
\hline & 0.48 & 2 & 4 & 101.10 & $10 \%$ & \pm 1.67 & 2 & 8 & 98.18 \\
\hline & & 2 & 6 & 100.30 & powder & & 2 & 10 & 98.48 \\
\hline & & 2 & 10 & 98.80 & & & 2 & 12 & 101.37 \\
\hline $\begin{array}{l}\text { Mean } \pm \\
\text { RSD\% }\end{array}$ & \multicolumn{4}{|c|}{$100.70 \pm 1.58$} & $\begin{array}{l}\text { Mean } \pm \\
\text { RSD\% }\end{array}$ & \multicolumn{4}{|c|}{$99.93 \pm 1.85$} \\
\hline
\end{tabular}

$* n=4$

Table 5: Recovery of ER and FQ in their pharmaceutical formulations by the proposed densitometric procedure.

\begin{tabular}{|c|c|c|c|c|c|c|c|c|c|}
\hline \multicolumn{5}{|c|}{ Enrofloxacin } & \multicolumn{5}{|c|}{ Flumequine } \\
\hline & \multirow[b]{2}{*}{$\begin{array}{c}\text { Mean } \\
\pm \\
\text { RSD } \%\end{array}$} & \multicolumn{3}{|c|}{ Standard addition } & & \multirow[b]{2}{*}{$\begin{array}{l}\text { Mean } \pm \\
\text { RSD\% }\end{array}$} & \multicolumn{3}{|c|}{ Standard addition } \\
\hline & & $\begin{array}{l}\text { Taken } \\
\mu \mathrm{g} \mathrm{ml}^{-1}\end{array}$ & $\begin{array}{c}\text { Added } \\
\mu \mathrm{g} \mathrm{ml}^{-1}\end{array}$ & $\begin{array}{c}\text { Recovery } \\
\% \\
\text { of added }\end{array}$ & & & $\begin{array}{l}\text { Taken } \\
\mu \mathrm{g} \mathrm{ml}^{-1}\end{array}$ & $\begin{array}{l}\text { Added } \\
\mu \mathrm{g} \mathrm{ml}^{-1}\end{array}$ & $\begin{array}{c}\text { Recovery } \\
\% \\
\text { of added }\end{array}$ \\
\hline Enrotryl & $100.9 \pm$ & 1.5 & 1.0 & 100.8 & Flumequine & 99.6 & 4 & 2 & 101.6 \\
\hline $10 \%$ & 0.74 & 1.5 & 1.5 & 101.0 & $10 \%$ & \pm 0.88 & 4 & 4 & 101.0 \\
\hline inj. & & 1.5 & 2.0 & 100.6 & powder & & 4 & 6 & 98.2 \\
\hline & & 1.5 & 2.5 & 100.5 & & & 4 & 8 & 100.6 \\
\hline $\begin{array}{l}\text { Mean } \pm \\
\text { RSD\% }\end{array}$ & \multicolumn{4}{|c|}{$100.7 \pm 0.22$} & $\begin{array}{l}\text { Mean } \pm \\
\text { RSD\% }\end{array}$ & \multicolumn{4}{|c|}{$100.3 \pm 1.49$} \\
\hline
\end{tabular}


Table 6: Statistical analysis of the results obtained by the two proposed and reported procedures for the determination of ER and FQ in their pharmaceutical formulations.

\begin{tabular}{||c|c|c|c|c|c|c|}
\hline \multirow{2}{*}{ Parameters } & \multicolumn{3}{|c|}{ Enrotryl 10\% Injection } & \multicolumn{3}{c|}{ Flumequine 10\% powder } \\
\cline { 2 - 7 } & $\begin{array}{c}\text { Reported* } \\
\text { Procedure }\end{array}$ & $\begin{array}{c}{ }^{1} \mathrm{DD} \\
\text { Procedure }\end{array}$ & $\begin{array}{c}\text { Densitometric } \\
\text { Procedure }\end{array}$ & $\begin{array}{c}\text { Reported** } \\
\text { Procedure }\end{array}$ & $\begin{array}{c}{ }^{1} \text { DD } \\
\text { Procedure }\end{array}$ & $\begin{array}{c}\text { Densitometric } \\
\text { Procedure }\end{array}$ \\
\hline $\begin{array}{l}\text { Linearity } \\
\text { range }\left(\mathrm{gml}^{-1}\right)\end{array}$ & $60-130$ & $1-12$ & $1.5-4$ & $60-130$ & $2-14$ & $4-14$ \\
\hline $\mathrm{N}$ & 5 & 5 & 5 & 5 & 5 & 5 \\
\hline Mean, \% & 100.20 & 100.8 & 100.9 & 99.6 & 100.1 & 99.6 \\
\hline S.D, \pm & 0.54 & 0.48 & 0.74 & 0.78 & 1.67 & 0.88 \\
\hline Variance & 0.29 & 0.23 & 0.54 & 0.61 & 2.78 & 0.77 \\
\hline $\mathrm{t}$ & - & 1.86 & 1.75 & - & 1.04 & 0.19 \\
\hline $\mathrm{F}$ & - & 1.26 & 1.86 & - & 4.6 & 1.26 \\
\hline
\end{tabular}

The theoretical value of $\mathrm{F}=6.39$ and $\mathrm{t}=2.31$ at $(\mathrm{p}=0.05)$.

* ER was determined by chelation with iron (III) in water and the obtained yellow coloured complex was measured at $434 \mathrm{~nm}^{7}$

** FQ was determined by chelation with iron (III) at $\mathrm{pH} 3$ in dimethyl formamide medium, yellow complex was measured at $384 \mathrm{~nm}^{16}$

\section{REFERENCES}

1- J. F. Prescot and J. D. Baggot, "Antimicrobial Therapy In Veterinary Medicine", $2^{\text {nd }}$ edition, Iowa State University Press, USA (1993).

2- R. Jain and C. L. Jain, J. Liquid Chromatography and Gas Chromatography, 10 (9), 707-708 (1992). Through Anal. Abst. CD, Royal Society of Chemistry, Cambridge-UK (2002).

3- M. Horie, K. Saito, N. Nose and H. Nakazawa, J. Chromatogr. Biomed. Appl., 653 (1), 69 (1994).

4- J. Manceau, M. Giequel, M. Laurentie and P. Sanders, J. Chromatogr. Biomed. Appl., 765 (1-2), 175 (1999).

5- J. E. Royal, AP. Pfenning, S. B. TurniPseed, C. C. Walker and J. A. Hurlbut, J. Association Official Analytical Chemistry Int., 80 (5), 982-987 (1997).

6- E. Soczewinski and M. Wojciak-kosior, J. Planar-Chromatogr. Mod. TLC, 14 (1) 2833 (2001).

7- Z. A. El-Sherif, Anal. Lett., 32 (1) 65-78 (1999).
8- Samia, M.; Mohamed, E. S. and Esmail, A., J. Pharm. Biomed. Anal., 27 (1-2), 133 (2002).

9- M. Rizk, F. Belal, F. Ibrahim, S. Ahmed and N. M. El-Enany, J. Pharm. Biomed. Anal., 24 (2) 211-218 (2000).

10- M. Touraki, M. Landoukakis and C. Prokopiou, J. Chromatogr. Biomed. Appl., 751 (2); 247 (2001).

11- R. Gonazalez, L. Nuevas, L. Soto, M. Lopez and J. Hoogmrtens, J. Liq. Chromatogr. Relat. Technol., 24 (15), 2315 (2001).

12- G. Y. Eng, R. J. Maxwell, E. Chohen, E. G. Piotrowesk and W. Fiddler, J. Chromatogr., 799 (1-2), 349 (1998).

13- S. Thangadurai, S. K. Shulka and Y. Anjaneyulu, Analytical Science, 18 (1), 97 (2002).

14- M. Vega, G. Rios, R. Saelzer and E. Herliz J. Planar. Chromatogr. Mod. TLC., 8 (5), 378-381 (1995).

15- D. Barron, E. Jemeniz-Lozano, J. Cano and J. Babosa, J. Chromatogr. B, 759 (1) 73-79 (2001). 
16- F. M. Abdel-gawad and F. M. Abou-Attia, Microchem. J., 50 (1), 106-110 (1994).

17- F. Belal and M. Sharaf El-Din, Microchem. J., 42 (3) 300-305 (1990).

18- Wilson and O. Gisvold and R. F. Doerge, "Wilson and Gisvold's TextBook of Organic and Pharmaceutical Chemistry", $9^{\text {th }}$ ed. Lippincott J. B., New York, 1991, pp. 154-158.
19- Sonia, Z. K.; Sawsan, A. A. and Amer, M. M., J. Pharm. Biomed. Anal., 17, 826 (1998).

20- Claude Mazuel, In: "Analytical Profile of Drug Substance", K Florey, (Editor), Vol. 20, Academic Press, New York, 1991, pp. 557-600. 